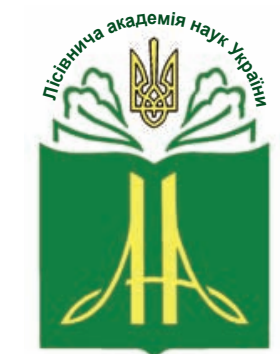

Forestry Academy of Sciences of Ukraine
Наукові праці Лісівничої академії наук України Proceedings of the Forestry Academy of Sciences of Ukraine http://fasu.nltu.edu.ua https://doi.org/10.15421/412102

Article received 2020.11.18

Article accepted 2021.06.10
ISSN 1991-606X print

ISSN 2616-5015 online

(a) $\triangle$ Correspondence author

ecoinst08@ukr.net
Pavlo Yashchenko

Kozelnitska str., 4, Lviv, 79026, Ukraine

УДК 630*907.11; 502.72(477.84)

\title{
Сильватизація оселищ лучно-степової рослинності та безхребетних у природоохоронних об'єктах Гологірського горбогір'я (природоохоронне оцінювання явища)
}

\author{
П.Т. Ященко ${ }^{1}$, Ю. В. Канарськийㄹ, І. М. Шпаківська
}

В останні десятиліття в Україні переглядають парадигму абсолютної заповідності і застосовують перехід на оселищні (габітатні) засади охорони біорізноманіття. Такий підхід зумовлений тим, щьо застосування лише заповідного режиму для збереження раритетів флори і рідкісних рослинних угруповань не забезпечує цілковитого збереження їх первинного складу і структури. Така ситуація характерна для природоохоронних об'єктів Гологірського горбогір'я, у яких збереглися ділянки екстразональної лучно-степової рослинності як оселища рідкісних видів рослин і комах. У статті охарактеризовано природні особливості Гологір, висвітлено історію створення у регіоні природоохоронних об 'єктів. Відзначено, що ботанічну пам'ятку природи державного значення «Лиса Гора і Гора Сипуха» площею 283 га було створено для охорони бучин чагарникових. Проте в офіиійному описі рослинності иього об'єкта зазначено, що на степових ділянках у його межах ростуть види трав, занесені до Червоної книги України. Це посилання свідчить, що пам'ятка природи мала подвійну мету - збереження не лише бучин чагарникових, але й лучно-степової рослинності з рідкісними представниками флори і фауни Украӥни, що підтверджує значну созологічну цінність об'єкта. Поряд з цим, штучне заліснення вершини гори Лисої деревними видами - Pinus sylvestris L. ma P. banksiana Lamb. й подальше спонтанне їх розселення на степові ділянки негативно позначається на збереженні трав'яної рослинності та угрупованнях безхребетних.

Аналіз наукових джерел щодо поширення сосни на Поділлі в минулому відображає розбіжність поглядів учених на її автохтонність. Вилив заліснення (сильватизації) оселищ лучно-степової рослинності та безхребетних охарактеризовано з природоохоронних позищій. Зроблено висновок, що наявність сосни в природоохоронних об'єктах Гологір не відповідає меті їх створення, а спонтанне поширення цієї породи призводить до деградаиії середовищ існування лучно-степової рослинності і угруповань комах, які підлягають охороні. Як наслідок - зникає цілий ксерофільний комплекс карабідофауни. Загальний аналіз трендів зміни чисельності окремих біотопічних груп денних метеликів у лучно-степових оселищах Гологір за останні 25 років показав значне змен-

\footnotetext{
Ященко Павло Тихонович - член-кореспондент Лісівничої академії наук України, кандидат біологічних наук, доцент, старший науковий співробітник відділу екосистемології Інституту екології Карпат НАН України, вул. Козельницька, 4, м. Львів, 79026, Україна. Тел.: +38-097-344-74-82. E-mail: ecoinst08@ukr.net; E-mail: home@mail.lviv.ua ORCID: 0000-0002-9246-9978

2 Канарський Юрій Васильович - кандидат біологічних наук, старший науковий співробітник відділу екосистемології Інституту екології Карпат НАН України, вул. Козельницька, 4, м. Львів, 79026, Україна. Тел.: +38-067-602-51-22. E-mail:ykanarsky@gmail.com ORCID: 0000-0002-8426-3072

3 Шпаківська Ірина Миронівна - кандидат біологічних наук, старший науковий співробітник, завідувач відділу екосистемології Інституту екології Карпат НАН України, вул. Козельницька, 4, м. Львів, 79026, Україна. Тел.: +38-050-519-39-51. E-mail: ishpakivska@ukr.net ORCID: 0000-0002-5152-6083
} 
шення частоти трапляння екотонних мезофілів, степових ксерофілів і лучних гігрофілів. Доцільно застосувати активне збереження мезоксерофітних травостоїв та угруповань безхребетних шляхом регулярного вилучення з їхніх оселиш самосіву сосни і лішини.

Ключові слова: парадигма; ботанічні пам'ятки природи; ксеромезофітні трав'яні угруповання; лісові культури сосни; спонтанне заліснення схилів; рідкісні види рослин і комах.

Вступ. Упродовж останнього десятиліття в Україні дедалі частіше застосовують оселищний підхід до охорони біорізноманіття, зокрема до збереження локалітетів рідкісних видів рослин і тварин та їхніх угруповань. Ця концепція стала базовою для формування екологічної мережі держави, що охоплює як об' єкти природно-заповідного фонду, так і трансформовані людиною території, (в т.ч. i техногенні), передбачає природоохоронну їх оцінку як умов існування певних угруповань чи окремих видів (Кагало та ін., 2012; Davies, Moss, \& O'Hill, 2004). На важливості управління збереженням біорізноманіття на рівні пріоритетних типів біотопів (як місцезнаходжень рідкісних типів угруповань) чи оселищ (як локалітетів окремих видів рослин) наголошує, зокрема, Директива Ради Європи 92/43/Е/СЕС від 21 травня 1992 р. «Про збереження природних типів оселищ (habitats) та видів природної фауни й флори» (Директива..., 2012). У ній прямо зазначено, що «...збереження біорізноманіття у певних випадках може потребувати здійснення людиною певних заходів чи спонукання до цього» (с. 29). Наведене відображає доцільність у багатьох випадках заміни парадигми абсолютного заповідання на оселищну та потребу застосування методів активної охорони біорізноманіття в об'єктах природно-заповідного фонду (ПЗФ).

Необхідність перегляду парадигми абсолютного заповідання зумовлена не тільки переходом України на загальноєвропейські критерії охорони природи, а й результатами аналізу багаторічного досвіду застосування заповідного режиму для збереження раритетів флори і рідкісних рослинних угруповань. Доведено, що застосування у минулому принципу абсолютної заповідності (Штильмарк, 1981, $1985)$ для охорони, наприклад степової рослинності, не забезпечує цілковитого збереження первинної структури ксеромезофітних угруповань та їхнього видового складу (Краснитский, Сошнин, 1984; Самарин, 1982; Семенова-Тян-Шанская, 1982). Після заповідання відбувається заліснення (сильватизація) степових ділянок, змінюються екологічні параметри охоронюваних фітоценозів, що зумовлює їхню деградацію і зникнення рідкісних видів рослин, які перебували під охороною (Ященко, 2010). Такі зміни зумовлені й суто біологічними причинами, зокрема посиленням сукцесій рослинності внаслідок переходу на природний шлях іiі розвитку. У нових екологічних і фітоценотичних умовах змінюється численність видів флори і фауни, їхнє домінування і структура рослинного покриву.
Абсолютне заповідання добре спрацьовує в умовах дуже великих за площею лісових об'єктів, створених для збереження рідкісних видів тварин (наприклад, Баргузинський заповідник у Сибіру, площа якого - понад 1 млн га і основне завдання - збереження соболя). Але в більшості природоохоронних об'єктів, які охороняються в Україні і площа яких порівняно невелика, після заповідання змінюються екологічна ситуація і початкове біорізноманіття. У степах розпочинаються спонтанні процеси їх заліснення, кущі та дерева формують яруси i витісняють трав'яні угруповання. Притінення травостою зумовлює випадання багатьох геліофітів, і в підсумку - деградацію степових фітоценозів (Ткаченко, 2004). Подібне явище спостережено й на луках, формування і функціонування яких відбувається переважно за участі людини. У лісостепу в заказниках також змінюється функціональна роль синузій кущів і дерев, посилюється роль чагарникового ярусу і відбувається зміна домінантів трав'яного покриву. Внаслідок цього втрачається початкова мета заповідання - збереження лісостепового біорізноманіття, зокрема трав'яних мезоксерофітних фітоценозів та угруповань безхребетних. Такі зміни відбуваються і на території природоохоронних об'єктів Гологірського горбогір'я, в яких збереглася лучно-степова рослинність, але триває іiі витіснення внаслідок спонтанного заліснення травостоїв (рис. 1, 2).

Спонтанне заліснення степових ділянок у ботанічній пам'ятці природи державного значення «Лиса Гора та Гора Сипуха» призводить до втрати оселищ екстразональної мезоксерофітної рослинності, рідкісних видів рослин і комах. Така ситуація свідчить про потребу пошуку шляхів збереження первинних лучно-степових екосистем, зокрема і через сповільнення процесів їх сильватизації. Розгляд цих проблемних питань відображає актуальність досліджень та їхню природоохоронну важливість.

Об'скти та методика досліджень. Об' $є$ стом досліджень є оселища лучно-степової рослинності у природоохоронних об'єктах Гологірського горбогір'я та створені наприкінці XX ст. лісові культури за участю Pinus sylvestris L. ma P. banksiana Lamb. у межах ботанічної пам'ятки природи державного значення «Лиса Гора та Гора Сипуха» як джерело спонтанного заліснення сосною трав'яних мезоксерофітних угруповань. Предмет досліджень - фітоценотична структура лучностепової рослинності, іiі зміни внаслідок природного заліснення оселищ сосною в умовах заповідного 
режиму, історичні особливості поширення сосни на Поділлі, зміни видового складу угруповань безхребетних внаслідок сильватизації, шляхи збереження оселищ лучно-степової рослинності. Мета досліджень - докладно дослідити особливості трансформаційних процесів у рослинному покриві природоохоронних об'єктів Гологірського горбогір'я в умовах заповідання, здійснити природоохоронне оцінювання явища сильватизації.

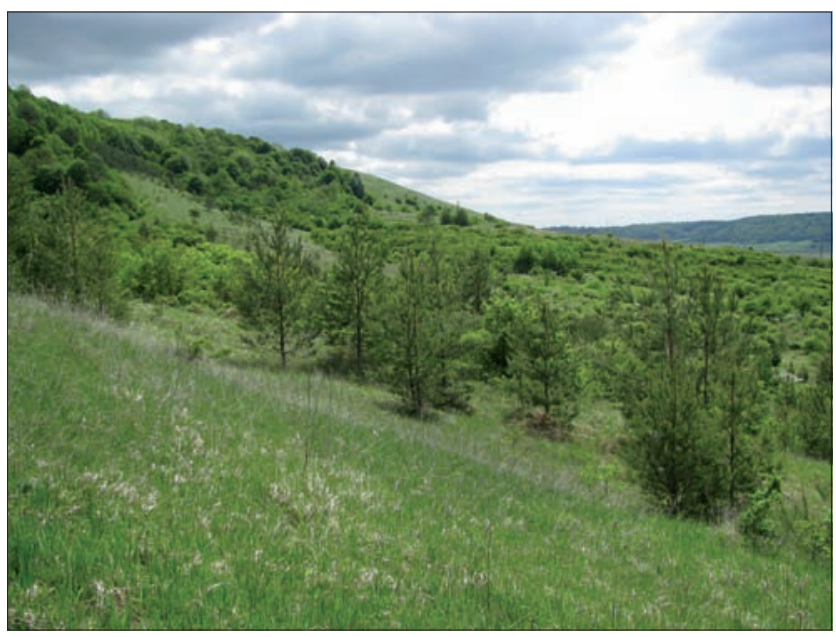

Рис. 1. Заліснення степових ділянок у ботанічній пам'ятці природи державного значення «Лиса Гора та Гора Сипуха» (літній аспект)

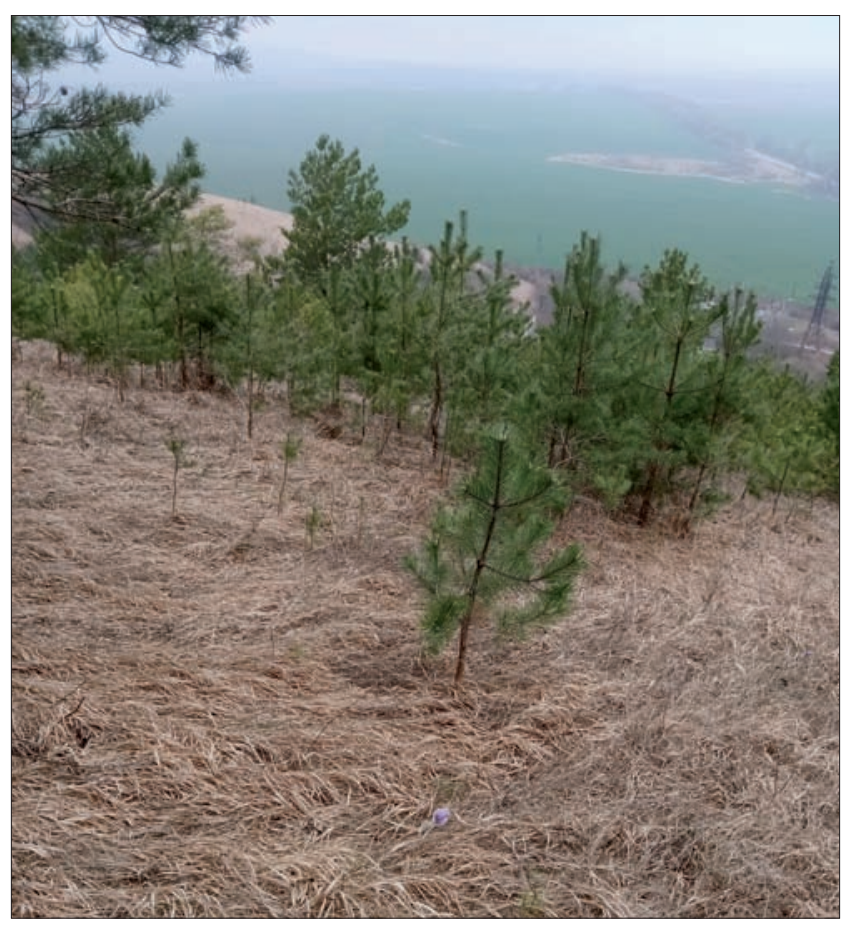

Рис. 2. Заліснення сосною степових ділянок на горі Лиса (ранньовесняний аспект)

Для досягнення зазначеної мети визначено основні завдання дослідження: розглянути причини зміни парадигми заповідання; охарактеризувати природні умови Гологір; з'ясувати історію створення природоохоронних об'єктів у Гологорах; узагальнити прояви сильватизації оселищ лучностепової рослинності на Лисій горі в умовах заповідання; проаналізувати роль наявних тут лісових культур сосни у процесах заліснення; розглянути історичні аспекти досліджень щодо поширення сосни на Поділлі та доцільність иіi збереження у природоохоронних об'єктах Гологір; охарактеризувати зміну видового складу угруповань безхребетних внаслідок заліснення оселищ лучно-степової рослинності у природоохоронних об'єктах Гологір; дати природоохоронну оцінку сильватизації оселищ лучно-степової рослинності, показати важливість активного їх збереження в умовах Гологірського горбогір'я.

Вивчення залісненості оселищ лучно-степової рослинності у природоохоронних об'єктах Гологір здійснено класичними геоботанічними і лісівничими методами польових досліджень (Воробйов, 1967; Программа..., 1974; Корчагин, 1976; Горшенин, Швыденко, 1977).

Для характеристики процесу сильватизації застосовано методичні лісівничі прийоми (облік природного поновлення дерев на пробних площадках, визначення його зімкнутості і породного складу). Видове різноманіття в оселищах вивчено на пробних площах та маршрутним методом обстеження природоохоронних об'єктів для якнайповнішого охоплення варіабельності заліснення на всій досліджуваній території (Кагало та ін., 2012). Для відображення історичних аспектів досліджень поширення сосни на Поділлі та змін видового складу флори здійснено аналіз літературних джерел, які стосуються Лисої гори й опубліковані впродовж попередніх століть. Назви рослин подано за Д.Н. Доброчаєвою та ін. (1987). Зміни видового складу безхребетних оцінено за допомогою ретроспективного аналізу літературних джерел (Romaniszyn \& Schille, 1929; Kuntze, 1936; Лазорко, 1938) та сучасних досліджень, що проводили від 1995 року. Зміни екологічних параметрів грунтів внаслідок заліснення та погоризонтний аналіз їх фізико-хімічних характеристик здійснено на основі відповідних грунтознавчих методик (Почвоведение...1975; ДСТУ 4289:2004).

Польові дослідження безхребетних здійснювали за загальноприйнятими для окремих таксономічних груп методиками, зокрема епігеобіонтних нелітаючих комах (турунів) - за допомогою грунтових пасток Барбера, а лускокрилих - методами виявлення та обліку на маршрутах (Фасулати, 1971; Канарський, 2006). Визначення комах здійснювали за сучасними визначниками (Freude, Harde, Lohse, \& Klausnitzer, 2004; Канарський, 2007), а їхні наукові назви скориговано за сучасними систематичними опрацюваннями відповідних таксономічних груп для фаун Свропи і Палеарктики (Lobl, Smetana, 2003; Kudrna, Pennerstorfer, \& Lux, 2015).

Результати та обговорення. Природнича характеристика Гологір $i$ їх созологічне значення. Ботанічна пам'ятка природи державного значення «Лиса Гора і Гора Сипуха» розташована в межах Гологірського горбогір'я, яке є частиною Гологоро- 
Кременецького кряжу, має ширину близько 10 км та довжину до 45 км і простягається від м. Бібрка до с. Плугів Золочівського району Львівської області (Ляска, 2017). Досить своєрідною є орографічна структура цього низькогірного пасма, яка має асиметричну будову: один схил, обернений до півночі, утворює досить стрімкий уступ, який піднімається на понад 100 м над прилеглими рівнинами Малого Полісся, тоді як південний схил пологий і поступово переходить у Перемишлянське горбогір'я. Максимальні висоти Гологір зосереджені у західній (г. Камула - 471 м; г. Замчисько 452 м; г. Нахорди - 401 м н.р.м.) та центральній частинах кряжу (гори Вапнярка - 460 м та Лиса 412 м н.р.м.). Гологорами пролягає Головний Свропейський вододіл.

Специфіка рельєфу та близьке до поверхні залягання вапняків, мергелів, пісковиків зумовили формування у межах Гологірського структурноденудаційного горбогір'я специфічних грунтів. Зональні їхні типи представлені дерновокарбонатними відмінами та чорноземами карбонатними, які сформувалися на карбонатних підстильних породах. Здійснені нами впродовж 2020-2021 pp. дослідження грунтів показали, що зональні їхні типи є важко- та середньосуглинковими, слабощебенистими, багатогумусними, реакція грунтового розчину слаболужна. Спонтанне заростання степових ділянок на горі Лисій соснами звичайною та Банкса зумовлює трансформацію властивостей грунтів. Змінюється їхній макроагрегатний склад, зокрема коефіцієнт структурності, який на степових ділянках становить 2,43, тоді як під лісовими лише 1,47 . Унаслідок хвойного опаду також змінюється кислотність верхнього гумусового горизонту: за значеннями $\mathrm{pH}$ водного розчину грунти зі слаболужних трансформуються у нейтральні.

Природні умови зумовили формування у цьому регіоні багатьох ділянок специфічної лучностепової трав'яної рослинності, що сприяло збереженню багатьох рідкісних видів рослин і комах. Проте загалом Гологори досить лісисті. Панівні тут грабово-букові та грабово-дубові ліси чергуються 3 ділянками мезоксерофітних трав'яних фітоценозів, що зумовлює не тільки строкатість рослинного покриву і багатство фіторізноманіття, але й значну напруженість конкурентних відносин між Лісом і Степом. Соснових лісів небагато і вони штучного походження.

Гологірське горбогір'я має важливе природоохоронне значення. Лучно-степова рослинність тут перебуває на північній межі поширення, тому наприкінці 70-х -на початку 80-х рp. XX ст. у регіоні було виділено низку ботанічних пам'яток природи місцевого значення, причому для охорони саме степових ділянок (Одноралов та ін., 1986). Зокрема, 02.10.1970 р. гора «Лиса» разом із горами «Сипуха» та «Стінка», схили яких були вкриті мезоксерофітними травами (тому й «лиса», бо безліса), були оголошені комплексною пам'яткою природи місцевого значення площею 84,3 га. Як комп- лексні пам'ятки природи місцевого значення, були взяті під охорону також «Жулицька Гора», «Гора Макітра», «Підлиська або Гора Маркіяна Шашкевича», екстразональна степова рослинність яких відображала специфіку ландшафту Гологірського горбогір'я. У 1984 р. територію «Лисої Гори» було розширено доповненням ділянки прилеглих грабово-букових лісів, внаслідок чого площа цієї пам'ятки природи збільшилася до 283,0 га (Ляска, 2017). Оскільки охороні підлягали букові ліси, то відповідальною організацією за їх збереження було призначено Золочівське лісництво Золочівського держлісгоспу Львівського обласного управління лісового господарства. Указом президента України від 20.08.1996 р. № 715/96 «...3 метою збереження унікальної у геоморфологічному відношенні території, вкритої високопродуктивними мішаними лісами $з$ рідкісними угрупованнями бучин чагарникових» цьому об'єкту площею 283 га було надано статус «ботанічна пам’ятка природи державного значення "Лиса Гора і Гора Сипуха"».

Хоча офіційно під охорону було взято бучини чагарникові, але в описі рослинності ботанічної пам'ятки природи зазначено, що на їі території представлені місцезростання таких видів трав, як Lunaria rediviva L. та Orchis ustulata L., які занесено до Червоної книги України. Тут росли також і такі рідкісні види рослин, як Carlina onopordifolia Bess. ex Szaf., Kulcz. et Pawl., Pulsatilla grandis Wend. та Orchis militaris L. Ці флористичні елементи свідчать, що пам'ятка природи фактично мала (і має!) подвійне призначення - охорону не лише бучин чагарникових, але й екстразональної лучно-степової рослинності та наявних тут локалітетів рідкісних представників флори Львівщини, що підтверджує значну созологічну цінність об'єкта. Тому заростання деревами і кущами ділянок трав' яної рослинності на схилах гори Лисої є процесом небажаним, бо призводить до витіснення видів лучно-степової флори та їх угруповань, а також пов’язаних 3 ними рідкісних видів безхребетних.

Конкурентні відносини між травами, деревами i кущами ще більше загострилися після створення на вершині гори Лисої лісових культур Pinus sylvestris. Давня класична проблема «Ліс і Степ» тут стала проявлятися повною мірою. Активізація за останні десятиліття процесів спонтанного заліснення лучностепових ділянок, особливо за участю алохтонної сосни, потребує фітосозологічної інтерпретації цього явища і прийняття природоохоронних заходів для збереження трав'яної мезоксерофітної рослинності та комплексу угруповань безхребетних.

На формування рослинного покриву Гологір мали значний вплив і трансформаційні події минулих століть, зокрема військового характеру. Так, історичні джерела свідчать про ведення у далекому минулому на горі Лисій бойових дій (Ляска, 2017), що потребувало відкритого простору. Це підтверджує давність наявності тут оголених остепнених ділянок рослинності. 
Зміни лучно-степової рослинності внаслідок заліснення. Верхня частина схилу ботанічної пам'ятки природи загальнодержавного значення «Лиса Гора та Гора Сипуха» вкрита лісовими культурами сосни, створеними наприкінці 70-х років $\mathrm{XX}$ ст. для припинення подальшого розмиву грунту. Лісорослинні умови ділянки - свіжі сугруди, потенційний тип лісу - грабова субучина. Про це свідчить наявність природного поновлення Carpinus betulus L. під наметом деревостану на північно-східному крутосхилі та перевага мегатрофів-мезофітів у сучасному трав'яному покриві. Тут ростуть Corydalis cava Schweigg. et. Korte., Galanthus nivalis L., Anemone ranunculoides L., A. nemorosa L., Asarum europaeum L., Scilla bifolia L., Pulmonaria officinalis Dumort. На сьогодні сосна інтенсивно насіннєносить, іï насіння вітер заносить на трав'яні ділянки, де підріст сосни розташовується поодиноко та куртинами (до 2 тис. особин на 1 га). Вік соснового підросту - від однорічок до 15 років, а висота окремих особин становить понад 2 метри.

Окремими смугами вздовж схилу сформувалися густі (зімкнутість намету - до 0,8) зарості Corylus avellana L., що спонтанно утворилися на згарищах лучно-степової рослинності та на ділянках колишніх орних земель. У наземному покриві ліщинників переважає Anemone nemorosa, трапляється Asarum europaeum.

Безлісі схили зайняті трав'яними угрупованнями 3 домінуванням Carex humilis Leuss, C. montana L., Brachipodium pinnatum (L.) P. B., Inula ensifolia L. Y формуванні трав'яного покриву беруть участь також Festuca ovina L., Elytrigia intermedia (Host.) Nevski, Poa angustifolia L., Briza media L., Teucrium chamaedris L. Трапляються також Anthericum ramosum L., Festuca sulcata Hack., Helictotrichon pratense (L.) Bess., Koeleria gracilis Pers., Potentilla arenaria Borkh., Carlina cirsioides Klok., C. onopordifolia Bess.). Із ранньоквітучих рослин відмічені Pulsatilla latifolia Rupr., P. grandis Wender, Primula veris L., Adonis vernalis L., Daphne cneorum L.

Потрібно зазначити, що створення лісових культур сосни загальмувало ерозійні процеси на схилах, але сосновий ліс став джерелом спонтанного заліснення прилеглих лучно-степових ділянок. Експансія сосни та ліщини призводить до посилення затінення й витіснення багатьох видів трав зі складу лучно-степових травостоїв. Питання сильватизації і збереження лучно-степової рослинності набуло особливої уваги після створення 11 лютого 2009 р. Національного природного парку «Північне Поділля», до якого включено більшість зазначених пам'яток природи з оселищами лучно-степової рослинності, в яких активно відбуваються трансформаційні процеси. Офіційно ж охороні на Лисій горі і надалі підлягають «...високопродуктивні мішані ліси з рідкісними угрупованнями бучин чагарникових».

Штучне заліснення вершини гори Лисої, а тим більше використання для цього сосни, неодноразово викликало заперечення ботаніків, які відстою- вали важливість збереження саме лучно-степових ділянок. Не схвалюють заліснення сосною ділянок степової рослинності і багато вчених-екологів. Штучно впроваджена сосна не $є$ компонентом природного біорізноманіття у ботанічній пам'ятці природи. До того ж питання автохтонності сосни на Поділлі, а особливо на сухих схилах високих горбів у Гологорах, і в історичному плані трактувалося неоднозначно.

Сосна на Поділлі перебуває на південній межі поширення, іiі природність у регіоні заперечувало багато дослідників в минулих століттях. Проте окремі відомі лісівники й ботаніки обстоювали тезу про природний характер поширення сосни у далекому минулому, допускали можливість збереження природних осередків цієї породи фактично до XVIII століття. Тому питання - чи підлягає сосна охороні в пам'ятці природи «Лиса Гора i Гора Сипуха», як складовій НПП «Північне Поділля», чи спонтанне іiі розселення варто блокувати - потребує поглибленого розгляду хорологічної специфіки цієї породи, її походження і поширення на Поділлі в історичному аспекті.

Історичні етапи досліджень ареалу сосни та iï походження на Поділлі. Походження і поширення Pinus sylvestris на Поділлі, зокрема проходження південної межі іiі ареалу, вивчало багато вчених, особливо у XVIII-XIX століттях. Це питання порушено у багатьох публікаціях. Так, детальний історичний аналіз досліджень щодо походження і трапляння деревного виду у регіоні, специфіки його ареалу та розгляд господарського значення викладено у кандидатській дисертації В.П. Ковалишина «Сосна обыкновенная как быстрорастущая и перспективная порода в культурах Западного Подолья» (Ковалишин, 1971).

Автор розглядає декілька періодів, коли питання автохтонності чи алохтонності сосни у регіоні набувало особливої уваги. Це, зокрема, період до 1910 р., який умовно названо «австро-угорський», коли поширення сосни у регіоні та iï природність досліджувала низка авторів (Holowkiewicz, 1890; Strzelecki, 1894; Sokolowski, 1901 та ін.). У період «польсько-український», а саме - впродовж 19101939 рр., поширення сосни та $\dddot{1}$ походження на Поділлі вивчали українські й польські вчені (Szafer, 1910, 1935; Raciborski, 1911; Paczoski, 1913; Wierdak, 1925; 1927; Koczwara, 1925, 1928; Miklaszewski, 1928; Погребняк, 1931; Zajaczkowski, 1936; Gajewski, 1937). Період «радянський, повоєнний»від 1945 р., представлений дослідженнями українських учених (Косець, 1947; Бухало, 1961; Бутейко, 1963, 1975). Дані про сучасні соснові і букові ліси на Поділлі наведено у низці робіт (Криницький, Попадинець, Бондаренко, Крамарець та ін., 2004; Бондаренко та ін., 2006 та ін.).

Особливу увагу давні дослідники приділяли встановленню південної межі поширення Pinus sylvestris на Поділлі. Границю ареалу деревного виду в Європі, зокрема його південну межу, проводили власне по Поділлю (Ковалишин, 1971). Так, 
Ф. Кеппен (1885) межу суцільного поширення деревного виду проводив від східної межі Галичини серединою Волині, потім північною границею Київської області і серединою Чернігівщини, і далі на північний схід. Південніше від цієї лінії сосна представлена лише острівними осередками.

Південну границю сосни вчений узгоджував 3 ізотермою липня $22,5^{\circ}$, відзначаючи також збіг південної межі трапляння сосни 3 відомою геологічною межею, а саме - 3 південною граничною лінією поширення валунного лесового суглинку. Таку лінія провів В. В. Докучаєв (1883) північними схилами Галицько-Волинського плато, далі вона пролягала північною межею тодішніх Херсонської і Катеринославської областей України, потім - південною межею Курської і Воронезької губерній Росії. Цю межу Ф. Кеппен (1885) ототожнював із границею поширення льодовика, а острівний характер трапляння Pinus sylvestris південніше цієї межі пов'язував із грунтово-кліматичними умовами, в яких не можуть рости інші деревні види.

Однак поширення сосни на Поділлі і їі природність в історичному аспекті трактують неоднозначно. Зроблений В.П. Ковалишиним (1971) детальний огляд літератури з цього питання свідчить, що більшість відомих тогочасних вчених дотримувались думки про спорадичний характер трапляння цієї породи в регіоні. Зокрема, E. Holowkiewicz (1890) відзначав спорадичність поширення Pinus sylvestris; Ф. Кеппен (1885) зауважував, що цей вид зовсім не трапляється тут дикоросло. H. Strzelecki (1894) констатував відсутність сосни на Подільській височині і зазначав, що вона рідко трапляється лише у західній частині Опілля, однак насаджень природного походження тут немає.

Відсутність дикорослої сосни на Поділлі відзначали також S. Sokolowski (1901) та J. Miklaszewski (1928), які вважали, що хвойні види не властиві для умов Поділля і можуть тут рости тільки у виняткових випадках, зокрема на «стінках» Подільських Товтр, біля їх підніжжя, де можуть сформуватись відповідні для сосни умови місцезростання. Н. Zapalowicz (1906-1911) також зазначав, що на всій території Поділля не росте «первобутня» сосна, а трапляється тут лише поодиноко, причому штучного походження. Існування у Медобоpax хвойних лісочків штучного походження підтверджував W. Szafer (1910). На відсутність на Подільському плато дикорослої сосни вказував також M. Raciborski (1911).

Поряд 3 цим, деякі вчені дотримувалися протилежної думки. За В.П. Ковалишиним (1971), до таких належав, насамперед, W. Koczwara (1925, 1928), який стверджував, що наявність на Поділлі таких видів, як Dianthus caesius Smith та Vaccinium myrtillus L. вказує на те, що колись хвойні тут росли природньо. На думку W. Koczwara, цей аспект підтверджується також наявністю Daphne cneorum та Coronilla coronata L. у соснових лісах. На природність сосни у регіоні вказував також W. Gaewski (1937), який зазначав, що ізольовані подільські міс- цезростання рослин соснових лісів є, поза сумнівом, слідами постгляціальних лісів Поділля.

Наявність острівних місць виростання Pinus sylvestris природного походження на Опіллі відзначали також відомі й авторитетні польські дослідники (Wierdak, 1925, 1927; Kaminski, 1935; Zajączkowski, 1936). Посилаючись на вказівки цих авторів, В.П. Ковалишин (1971) наводив дані, згідно з якими на західній межі Поділля, а саме біля с. Урмань, яке розташоване на північ від м. Бережани Тернопільської обл., у тридцятих роках XX ст. на площі до 60 га існував природний сосновий деревостан віком 150-180 років. Окремі дерева у цьому лісостані мали діаметр до 120 см (середній діаметр насадження - 32 см) і висоту до 30 м. У другому ярусі переважали Fagus sylvatica L., Quercus robur L., Carpinus betulus L., у підрості - Pinus sylvestris, Fagus sylvatica, Quercus robur, Carpinus betulus, Ulmus glabra Huds., Cerasus avium (L.) Moench. Підлісок формували Corylus avellana, Euonymus verrucosa Scop., Euonymus europaea L., Viburnum opulus L., V. lantana L., Swida alba (L.) Opiz. Цей лісостан був розташований на південному схилі хребта, який опускався до лівого берега р. Золота Липа, i знаходився близько до південно-східної межі ареалу сосни звичайної.

На наявність на території Західного Поділля соснових субучин, причому як корінних, так і похідних деревостанів, вказувала О.І. Бутейко (1963, 1975). Такі ліси, трапляючись острівцями, у минулому займали найвищі положення рельєфу - вершини хребтів, підвищення на плато і схилах, тобто місця із вологішим мікрокліматом і меншою амплітудою коливань температури повітря. У деревостанах панували Pinus sylvestris I бонітету, Fagus sylvatica I бонітету і Carpinus betulus II бонітету. Як супутні породи відзначено Quercus robur, Acer platanoides L., A. pseudoplatanus L., Populus tremula L., Ulmus carpinifolia Rupp. ex G. Suckow, Cerasus avium. Сучасні ж соснові ліси на Поділлі O.І. Бутейко $(1963,1975)$ розглядала як залишки колишніх великих масивів сосняків, які існували в регіоні у польодовиковий період.

Враховуючи таку різнобічність поглядів і неоднозначність тверджень щодо природності походження Pinus sylvestris на Поділлі, В. П. Ковалишин (1971) наголошував на необхідності розглядати це питання 3 урахуванням історії польодовикового розвитку рослинного покриву цього регіону. Зокрема, історичні аспекти змін рослинності Поділля у польодовиковий час добре вивчив W. Szafer (1935), який за результатами споропилкового аналізу торфовищ виділяв п'ять періодів розвитку рослинного покриву регіону. Узагальнені періоди В.П. Ковалишин (1971) охарактеризував так.

1. Початковий період (кінець плейстоцену і початок голоцену - від 14000-8000 років до н.е.) - завершення зледеніння у Польщі. На Поділлі - холодний континентальний клімат (як у холодному степу). Pinus sylvestris росла куртинами, були наявні також Picea abies (L.) Karsten, Betula pendula Roth., 
а на прирічковому алювіi - зарості Alnus glutinosa (L.) Gaertn.

2. Етап появи теплолюбних порід (мезоліт, від 8000 до 6000 років до н.е.). Відбулося потепління клімату, виникли види роду Ulmus, і цей період $є$ часом їхнього максимального розвитку. На Західне Поділля проникає Quercus robur, формуючи у степу перші острівки лісів.

3. Період панування теплолюбних дерев (неоліт, 6000-3000 років до н.е.). Клімат теплішає до термічного оптимуму, середня річна температура вища, ніж сучасна. Проте поки що переважають степові комплекси, які мають вигляд пакового степу. Поряд 3 Quercus robur поширюються також Fraxinus excelsior L., Tilia cordata L., Corylus avellana, Cornus mas L., Staphyllea pinnata L. Pinus sylvestris у цей час на Поділлі відсутня, вона відступає з регіону, як і Picea abies. На території Медоборів з' являється Fagus sylvatica, який проникає із південного заходу.

4. Період найвологішого клімату (бронзова епоха, 3000-800 років до н.е). Клімат набуває лісових рис, на нагір'ях Поділля формуються букові ліси, граб домінує над дубом, утворюються угруповання Querceto-Carpinetum podolicum. Можливо, що в цей час на Поділлі росла Abies alba Mill., оскільки частка участі ïi пилку у пробах інколи буває значною - до $24 \%$.

5. Період вторинної континентальності клімату (передісторичний та історичний час, від 800 років до н.е. і до сучасності). Клімат стає сухішим, висихають торфовища, зменшується частка участі пилку листяних порід, тоді як хвойних - збільшується, особливо Pinus sylvestris. Букові ліси відступають і зникають. Посилюється вплив людини на рослинний покрив.

Гіпотезу W. Szafer (1935) про те, що у п’ятому періоді на Поділлі, поруч із листяними, могли рости і хвойні ліси $з$ переважанням Pinus sylvestris, підтримував W. Gaewski (1937). Ми також підтримуємо тезу про можливість існування фрагментів природних хвойних лісів на Поділлі на сьогодні, базуючись на результатах топонімічного аналізу наведеної В.П. Ковалишиним (1971) вказівки про наявність у минулому столітті хвойного лісу на березі р. Золота Липа полизу с. Урмань. Зокрема, стару церкву у цьому селі було збудовано у Прикарпатті і потім перевезено в село, датовано 1668 роком. Існують дані, що в 1626 р. село було поруйноване татарами. Писемні згадки про Урмань датовані 1385 р., саме ж село може бути значно древнішим, сягаючи корінням у ранні часи татаро-монгольської навали. Назва «урман» із тюркської перекладається як «хвойний ліс на заболочених ділянках рівнин чи вздовж річок». Так, назву «Урман» на сьогодні мають декілька сіл у Башкортостані та в Красноярському краї Росії. «Урман» - це також назва кількох тамтешніх річок. Саме цим терміном називають темнохвойний ліс (за участю ялиці, кедрової сосни, ялини) на прирічкових ділянках тайгової зони Західного Сибіру. Збереження єдиного в межах України топоніму «Урмань» за древнім селом на Терно- пільщині також може свідчити про наявність тут хвойного лісу у давні часи і його природне походження. Проте сучасні деревостани сосни на Поділлі мають вторинне походження.

Сучасне поширення сосни у Західному Поділлі. У сучасний період Pinus sylvestris на Поділлі не має значного поширення, а 11 деревостани мають антропогенне походження. Перші згадки про посадки сосни у регіоні датуються другою половиною XIX ст., коли такі роботи шляхом висіву насіння і висаджування саджанців уручну здійснювали у Борщівському й Чортківському районах (Ковалишин, 1971). На наявність старих лісових культур сосни в Медоборах вказували W. Szafer (1935), M. Zajaczkowski (1936), а також П. С. Погребняк (1931). Станом на 1971 р. були відомі лісові культури Pinus sylvestris у таких лісових дачах, як «Галілея» та «Росохач».

Однією із причин створення лісових культур сосни на Поділлі була цінність їі деревини для будівництва, а також для отримання живиці. Деревину сосни легко обробляти, на відміну від твердолистяних порід, зокрема граба і бука, деревину яких в минулому використовували переважно як дрова на паливо. Сосну також використовували для закріплення оголених схилів, оскільки вона є породою світлолюбною і може рости на бідних сухих грунтах, зокрема й на вапнякових. Саме з такою метою було створено лісові культури Pinus sylvestris i на горі Лисій.

Про роль насаджень сосни звичайної у сучасному рослинному покриві Поділля, зокрема Західного, свідчать такі дані. Загальна площа лісів, сформованих цим деревним видом, становить 10567 га або ж 8,6\% від площі вкритих лісовою рослинністю земель регіону. Більші площі займають лише дубові i букові ліси. Середній вік соснових лісостанів становить 49 років, більша частина яких має штучне походження. Сосна відзначається дуже добрим ростом, переважає клас бонітету - I, I (Бондаренко та ін., 2006; Криницький та ін., 2004). Таксаційний склад насаджень для Західноподільського лісокультурному округу має вигляд 6Дз1Бк 1 З $1 \mathrm{C}_{30}, 5$ Ял0,5Яс (Дебринюк, 2003).

Вплив штучного й спонтанного заліснення на угруповання безхребетних. Спонтанне заліснення лучно-степових ділянок у межах ботанічної пам'ятки природи державного значення «Лиса Гора i Гора Сипуха» негативно впливає на збереження оселищ степової флори і рослинності та фауни безхребетних. Внаслідок сильватизації на г. Лисій зникають оселища багатьох видів комах, які фіксували тут у попередні періоди досліджень ентомофауни. Це підтверджує ретроспективне оцінювання змін їхніх ареалів. Остання потребує високого рівня вивченості регіональної фауни впродовж достатньо тривалого часу, що є характерним для небагатьох регіонів і таксономічних груп. Одним із таких регіонів є Гологірське горбогірне пасмо, де систематичні дослідження ентомофауни проводили ще 3 середини XIX століття. Невеликі перерви у дослі- 
дженнях припали на дві світові війни та кілька десятиліть радянського періоду (приблизно 19601990 рр.). Проте після 90-х років вивчення ентомофауни регіону було продовжено. Особливо детально здійснюють дослідження на території НПП «Північне Поділля», до якого тепер належать колишні пам'ятки природи, в яких охороняється мезоксерофітна рослинність.

Негативний вплив заліснення оселищ лучностепової рослинності на угруповання безхребетних простежується на прикладі результатів досліджень, які від 1995 р. здійснюють в ур. «Лиса Гора і Гора Сипуха», «Біла (Підлиська) Гора», «Макітра», «Говда» та деяких інших. При цьому дослідники акцентують увагу на таких індикаторних групах комах, як жуки-туруни (Coleoptera: Carabidae) та денні (булавовусі) метелики (Lepidoptera: Rhopalocera).

Потрібно зазначити, що рідкісні і ті, що зникають, види безхребетних дуже часто приурочені до локально поширених екстразональних та азональних екосистем, зокрема лучно-степових ділянок. Власне ці оселища тепер зазнають негативного, а місцями - й катастрофічного впливу штучного і спонтанного заліснення, випалювання трави, господарського освоєння (розорювання, забудова), а відтак - подальшого зменшення площ і фрагментації оселищ, що відбувається на тлі кліматичних змін з погано передбачуваними для біотичних угруповань наслідками.

Зокрема, рідкісний, тепер внесений до Червоної книги України (2009) східно-європейський лісостеповий вид туруна Carabus estreicheri F.-W., траплявся в ур. Лиса гора (околиці сіл Вільшаниця i Червоне Золочівського р-ну) на ксеротермних виходах вапняків (Лазорко, 1938). Сучасними обстеженнями цей вид у зазначених локалітетах не виявлено, але віднайдено в інших, раніше відомих локалітетах на г. Макітра (околиці с. Гаї Дітковецькі Бродівського р-ну) і в околицях сіл Ясенів та Підгірці Бродівського району. Вид зберігся в оселищах, які не зазнали такого катастрофічного впливу сильватизації, як лучно-степова рослинність у ботанічній пам'ятці природи загальнодержавного значення «Лиса Гора та Гора Сипуха».

Східно-європейський лісостеповий вид Carabus excellens F. за давніми вказівками був звичайним на Північному Поділлі і на захід - до Розточчя (Lomnicki, 1890). На сьогодні його локалітети обмежені небагатьма оселищами лучно-степової рослинності у Гологоро-Вороняцькому пасмі, причому чисельність популяцій виду прогресивно зменшується.

Ще один східно-європейський степовий вид Carabus besseri F.-W. у межах НПП «Північне Поділля» тепер трапляється виключно в ур. «Лиса Гора», дуже локально населяючи найбільш екстремальні ксеротермні степові ділянки, хоча раніше був значно чисельніший та відомий навіть в околицях м. Львова (Kuntze, 1932, 1936; Lomnicki, 1890).

Загалом, унаслідок штучного й спонтанного заліснення лучно-степових ділянок, зникає цілий ксе- рофільний комплекс карабідофауни, зокрема такі види, як: Carabus besseri, C. estreicheri, C. excellens, C. scabriusculus Oliv., C. violaceus andrzejuscii F.-W., Poecilus sericeus F.-W., Pterostichus melas Creutz., Callistus lunatus F. тощо. Натомість з'являються характерні лісові види - Carabus coriaceus rugifer Krtz., C. glabratus Payk., Abax parallelopipedus Pill. et Mitt., A. parallelus Duft., Pterostichus melanarius Ill., $P$. niger Schall., P. oblongopunctatus F., Harpalus latus L. та ін.

Подібні зміни відбуваються й в угрупованнях денних метеликів, які особливо вразливі до змикання деревно-кущового ярусу на раніше «відкритих» лучно-болотних і лучно-степових оселищах (Рідкісні та зникаючі ..., 2013). Зокрема, досить звичайний у минулому на Розточчі, Опіллі та Малому Поліссі вид - Colias myrmidone Esp. (Hirschler, Romaniszyn, 1909; Romaniszyn, Schille, 1929) до кінця XX ст. зберігся, за нашими даними, лише на лучно-степових ділянках ГологороВороняцького пасма (ур. «Біла гора» поблизу с. Підлисся; ур. «Лиса Гора і Гора Сипуха»). У липні 1998 р. в урочищі «Біла Гора» він був масовим, причому траплялися всі кольорові його форми. У наступні роки цей вид на Гологоро-Вороняцькому пасмі не реєстрували, а кількість відомих його популяцій за останні 20 років різко зменшилася в Україні загалом. Як і згадані вище види турунів, цей вид також належить до східно-європейського лісостепового комплексу.

Процеси сильватизації лісостепових біотопів вірогідно призвели й до зникнення звичайного в минулому європейсько-сибірського виду Aporia crataegi L. Ще відносно недавно його вважали «злісним шкідником» плодових культур (Загайкевич, 1958), але у 2004 р. ми виявили лише єдину локальну його популяцію в ур. «Біла гора», а в наступні роки вид уже ніде не траплявся.

Подібну тенденцію демонструють два рідкісні ксерофільні лучно-степові види синявців - Роlyommatus damon D.-S. i P. dorylas D.-S. Перший був первинно дуже рідкісним і відомим лише 3 кількох локалітетів Західного Поділля (Гологори та Львівсько-Бережанське Опілля), а другий - локально поширеним на Розточчі, Західному Поділлі, у Вулканічних і Покутсько-Буковинських Карпатах (Hirschler, Romaniszyn, 1909; Romaniszyn, Schille, 1929). Одним із давніх локалітетів $P$. damon було вказано «Новосілки і Ляське (нині с. Червоне - прим. авт.) поблизу Золочева» (Romaniszyn, Schille, 1929), тобто, ур. «Лиса гора» i, можливо, деякі прилеглі до нього степові ділянки. Власне на Лисій горі ми вперше, після багаторічної перерви, виявили цей вид у 1995 р., реєстрували його там до 2009 р., після чого знахідок вже не було. Популяції P. dorylas також за останні 25 років значно зменшилися чисельно, проте й дотепер відзначаються у відомих раніше оселищах.

До рідкісних та тих, що зникають, метеликів регіону належать і такі характерні екотонні види, як Argynnis laodice Pall., Melitaea phoebe D.-S., Glauco- 
psyche alexis Poda, котрі тепер взагалі перебувають під загрозою зникнення у Львівській області (Рідкісні та зникаючі..., 2013).

Загальний аналіз трендів зміни чисельності окремих біотопних груп денних метеликів у лучностепових оселищах Гологоро-Вороняцького пасма за останні 25 років показав значне зменшення частоти трапляння екотонних мезофілів, степових ксерофілів і лучних гігрофілів, що, на нашу думку, зумовлено зміною просторової структури оселищ лучностепової рослинності внаслідок їх заростання деревами й кущами та утворення ними зімкненого намету. При цьому за останне десятиліття зникли три індикаторні види-маркери малопорушених екотонних оселищ (Colias myrmidone, Argynnis laodice, Melitaea diamina Lang) і єдиний вид - маркер унікальних лучно-степових оселищ Polyommatus damon.

Природоохоронне оцінювання явища сильватизації оселищ лучно-степової рослинності у Гологорах. Наведений вище історичний огляд літератури щодо природності Pinus sylvestris на Поділлі свідчить, що сучасні осередки соснових лісів тут мають вторинне походження. Наявність сосни на природоохоронних територіях у межах Гологірського горбогір'я не відповідає ні природоохоронній меті їх створення, ні природним типам лісових екосистем, а спонтанне розселення деревного виду по території призводить до деградації оселищ лучно-степової рослинності. Створюючи притінення, сосна витісняє лучно-степові види рослин, збіднює флористичне багатство природоохоронних об'єктів. Одночасно відбувається й зміна видового складу ентомофауни, збіднення видового різноманіття та випадання своєрідних еколого-біогеографічних комплексів безхребетних.

Така ситуація характерна і для колишньої ботанічної пам'ятки природи державного значення «Лиса Гора та Гора Сипуха», де відзначено інтенсивне заростання ділянок лучно-степової рослинності сосною та ліщиною. Заліснення відбувається у вигляді появи на трав'яних ділянках поодиноких особин і куртин сосни та кущів ліщини, а місцями формується зімкнутий деревно-кущовий покрив. Тому сильватизацію травостоїв на схилах розглядаємо як чинник негативний для збереження оселищ лучно-степової рослинності та їхнього біорізноманіття.

Висновки. Перебіг трансформаційних процесів у рослинному покриві природоохоронних об'єктів Гологірського горбогір'я в умовах заповідання підтверджує важливість застосування оселищної концепції збереження біорізноманітності. Аналіз спонтанного заліснення оселищ екстразональної лучно-степової рослинності на прикладі ботанічної пам'ятки природи державного значення «Лиса Гора і Гора Сипуха» свідчить про потребу застосування активної їх охорони. Результати досліджень потрібно розглядати як теоретичне підгрунтя практичної діяльності НПП «Північне Поділля» у напрямі збереження лучно-степової рослинності та фауни комах.
Потреба збереження первинної структури ксеромезофітних угруповань рослинності і безхребетних, їх просторової структури і видового складу, що не завжди забезпечується під час заповідання, свідчить про необхідність перегляду парадигми абсолютного заповідання, про важливість переходу на загальноєвропейські критерії охорони природи. Формування мережі природоохоронних об'єктів у Гологорах для охорони екстразональної лучно-степової рослинності та угруповань безхребетних, яке відбулося у 70-х роках XX ст., i вивчення стану їх збереженості та природоохоронне оцінювання змін має вагоме значення для практики охорони біорізноманіття як у межах національного природного парку, так і в регіоні Поділля загалом. Розвиток процесів заліснення оселищ мезоксерофітної рослинності, зокрема за участі сосни та ліщини, свідчить про посилення конкурентних відносин в угрупованнях екстразональної лучно-степової рослинності та потребу активного збереження біорізноманіття. Основним джерелом заліснення травостоїв у пам'ятці природи загальнодержавного значення «Лиса Гора та Гора Сипуха» $є$ лісові культури сосни. Історичний огляд літератури щодо автохтонності цієї породи на Поділлі відображає як значну зацікавленість цим питанням у XX ст., так і розбіжність оцінок щодо її походження і поширення у регіоні. Сучасна участь сосни у рослинному покриві Поділля, зокрема Гологірського горбогір'я, $є$ незначною.

Для збереження оселищ лучно-степової рослинності та угруповань безхребетних на горі Лисій потрібно вилучити самосів сосни й ліщини із ділянок мезоксерофітних трав. Такий захід треба застосувати і для інших природоохоронних територій у межах Гологірського горбогір'я, на яких збереглася й охороняється лучно-степова рослинність.

Аналіз сучасних змін видового складу жуківтурунів і денних метеликів у лучно-степових оселищах північно-західного Поділля також чітко відображає вплив двох основних чинників загрози різноманіттю їх угруповань, а саме - змін просторової структури оселищ унаслідок штучного й спонтанного заліснення та негативного впливу кліматичних змін. Тому вилучення самосіву сосни та кущів ліщини сприятиме також і збереженню оселищ рідкісних видів комах. Поряд 3 цим, наявні на «Лисій Горі та Горі Сипуха» лісові культури сосни відіграють фітомеліоративну роль, захищаючи верхів'я і схили цих підвищень від розмиву. Тому втручатися у подальший розвиток штучно створених сосняків доцільно лише з лісогосподарських позицій, застосовуючи необхідні протипожежні заходи їх локалізації для зменшення пожежної небезпеки. Вилучення самосіву сосни із ділянок трав'янистої рослинності зменшить також можливість переходу низових пожеж у верхові у разі загорання трави. Результати досліджень можуть бути використані у практичній діяльності НПП «Північне Поділля», зокрема щодо збереження оселищ лучно-степової рослинності. 


\section{Список літератури}

Бондаренко В. Д., Криницький Г. Т., Крамарець В. О., Музика М.Я., Попадинець І.М., Оліяр Г.І... Чернявський М.В. (2006). Стратегія і тактика природоохоронної діяльності лісового заповідника (на прикладі природного заповідника «Медобори») / за ред. Г.Т. Криницького. Львів: Сполом. 408 c. [Bondarenko, V.D. , Krynytsky, G.T., Kramarets, V.O., Musica, M.Ya., Popadynets, I.M., Oliyar, G. I. ... Chernyavsky, M. V. (2006). Strategy and tactics of nature protection activities of the forest reserve (on the example of "Medobory» nature reserve). Lviv: Spolom] (in Ukrainian)

Бутейко О. I. (1963). Соснові субучини, їх поширення і реставрація в західних областях УРСР. $M a-$ теріали до вивчення природних ресурсів Поділля. Тернопіль-Кременець, с. 43-45. [Buteyko, O.I. (1963). Pine-beech forests, their distribution and restoration in the western regions of the USSR. Materials to the study natural resources of Podillya (pp. 43-45). TernopilKremenets] (in Ukrainian)

Бутейко А.И. (1975). Сосново-буковые леса Запада Украинской ССР: автореф. ... канд. с.-х. наук: 06.093.03 / Львовский лесотехнический институт. Львов, 29 с. [Buteyko, A. I. (1975). Pine-beech forests of the West of Ukrainian SSR Abstract doctoral dissertation. Lviv Forestry Institute, Lviv, Ukraine] (in Ukrainian)

Бухало М.О. (1961). Флора і рослинність Гологір. Доповіді та повідомлення Львів. ун-ту, 9, ч. 2, 115-118. [Bukhalo, M.O. (1961). Flora and vegetation of the Holohory range. Reports and announcements of the Lviv University, 9 (2), 115-118] (in Ukrainian)

Воробьев Д.В. (1967). Методика лесотипологических исследований. Изд. 2-е., исправл. и дополн. Киев: Урожай, 383 c. [Vorobiev, D. V. (1967). Methodology for forest typological research. Edition 2., revised. and add. Kiev: Harvest] (in Russian)

Горшенин Н.М., Швыденко А.И. (1977). Лесоводство. Львов: Вища школа, 304 с. [Gorshenin, N.M., \& Shvydenko, A.I. (1977). Forestry. Lvov: High school] (in Russian)

ГродзінськийД. М., Шеляг-Сосонко Ю. Р., Черевченко Т.М., Смельянов І.Г., Собко В. Г., Лебеда А.П. (2001). Проблеми збереження та відновлення біорізноманіття в Украӥні. Київ: Видавничий дім «Академперіодика». 106 с. [Grodzinsky, D.M., Shelyag-Sosonko, Y.R., Cherevchenko, T.M., Yemelyanov, I. G., Sobko, V. G., \& Lebeda, A.P. (2001). Problems of the biodiversity conservation and restoration in Ukraine. Kyiv: Akademperiodyka Publishing House] (in Ukrainian)

Дебринюк Ю.М. (2003). Лісокультурне районування Західного Лicocmeny. Львів: Камула [Debryniuk, Iu. (2003). Forest zoning of the Western Foreststeppe of Ukraine. Lviv: Kamula] (in Ukrainian)

Директива Ради 92/43/СЕC від 21 травня 1992 року (2012). Про збереження природних оселищ та видів природної фауни й флори (1992). У кн.: Оселищна концепція збереження біорізноманіття: базові документи Європейського Союзу. Ред. О. О. Кагало, Б. Г. Проиьь. Львів: ЗУКЦ. С. 29-39. [Council Directive 92/43 / EEU of May 21, 1992 (2012). On the conservation of natural habitats and species of natural fauna and flora (1992). In O. O. Kagalo, B. G. Prots (Ed.), Habitat concept of biodiversity conservation: basic documents of EU (pp. 29-39). Lviv, ZUKC] (in Ukrainian)

Доброчаева Д.Н., Котов М.И., Прокудин Ю.Н., Барбарич А. И., Чопик В.И., Протопопова В. В.... Орнст Э.Й. (1987). Определитель высших растений Украиныл. Киев: Наукова думка. 548 с. [Dobrochaeva, D. N., Kotov, M. I., Prokudin, Y. N., Barbarych, A. I., Chopik, V. I., Protopopova, V. V. ... Ornst E.Y. (1987). Keys to higher plants of Ukraine. Kiev: Scientific thought] (in Russian)

Докучаев В.В. (1883). Русский чорнозем. Отчет Вольного экономического общесчтва. C почвенной картой и 12 рисунками в тексте. Санкт-Петербург, 376 с. [Dokuchaev, V.V. (1883). Russian black soil. Report of the Free Economical Society. With the soil map and 12 figures in the text. St. Petersburg] (in Russian)

ДСТУ 4289:2004 (2005). Якість грунту. Методи визначання органічної речовини. Київ: Держспоживстандарт України, 18 с. [DSTU 4289:2004 (2005). Soil quality. Methods for establishing organic speech. Kyiv: Derzhspozhivstandart of Ukraine] (in Urrainian)

Дылис Н.В. (1974). Программа и методика биогеоченотических исследований. Москва: Наука. 404 c. [Dylis, I. V. (1974). Program and methodology of biogeocenotic research. Moskow: Science] (in Russian)

Загайкевич I. К. (1958). Комахи - шкідники деревних $i$ чагарникових порід західних областей України. Київ: Вид-во АН УРСР. 134 с. [Zagaykevich, I.К. (1958). Insects - the pests of tree and shrub species in the western regions of Ukraine. Kyiv: Publishers of Academy of Sciences of the USSR] (in Ukrainian)

Кагало О.О., Круглов І.С., Данилик І.М., Проць Б. Г., Реслер І.Я., Кіш Р. Я. (2012). Біотопи (оселища) України: наукові засади їх дослідження та практичні результати інвентаризації. $M e$ тоди інвентаризачії оселим $і$ дослідження оселищної різноманітності (особливості підходів в Україні) : матеріали робочого семінару (м. Київ, 21-22 березня 2012 р.). Київ-Львів, 2012. С. 37-43. [Kagalo, O. O., Kruglov, I. S., Danylyk, I. M., Prots, B. G., Resler, I.Ya., \& Kish, R.Ya. (2012). Biotopes (habitats) of Ukraine: scientific principles of research and practical results of inventory. In Methods of the habitats inventory and research of habitat diversity (features of approaches in Ukraine), 37-43. Kyiv-Lviv, Ukraine] (in Ukrainian)

Канарський Ю. (2006). Про методику обліків і розрахунку чисельності денних лускокрилих. Вісник Львівського університету. Серія біологічна, 41, 63-70. [Kanarsky, Yu. (2006). To the methods of calculation and numbers account of the butterfly population for an aims of ecological; research. Bulletin of L'viv University. Biology Series, 41, 63-70] (in Ukrainian) 
Канарський Ю.В. (2007). Визначник денних метеликів західних регіонів України: Lepidoptera: Zygaenidae, Hesperioidea, Papilionoidea. Львів: Манускрипт. 112 с. [Kanarsky, Yu. (2007). Determination keys to the butterfl ies of the western regions of Ukraine: Lepidoptera: Zygaenidae, Hesperioidea, Papilionoidea. Lviv: Manuscript] (in Ukrainian)

Кеппен Ф. (1885). Географическое распространение хвойных дерев в Европейской России и на Кавказе. (С приложением, содержащим опыт разделения Европейской России на древеснорастительные области). Санкт-Петербург: Записки Имп. Академии наук. Приложение к т. 50, № 4. С. 634. [Keppen F. (1885) Geographical distribution of conifers in European Russia and the Caucasus. With an appendix containing the experience of dividing European Russia into forest vegetation regions. St. Petersburg: Notes of Imp. Academy of Sciences. Appendix to v. 50, N. 4, 634] (in Russian)

Ковалишин В.П. (1971). Сосна обыкновенная как быстрорастущая и перспективная порода в культурах Западного Подолья: дис. ... канд. с.-х. наук. Львовский сельскохозяйственный ин-т. Львов, 305 с. [Kovalyshyn, V.P. (1971). Common Pine as a fast-growing and promising species in the cultures of West Podolia. Doctoral dissertation, Lviv Agricultural Institute, Lviv, Ukraine] (in Russian)

Корчагин А.А. (1976). Строение растительных сообществ. Полевая геоботаника. Т. 5. Ленинград: Наука, Ленинградское отделение, 320 с. [Korchagin, A.A. (1976). The structure of plant communities. Field geobotany. Vol. 5. Leningrad: Science, Leningrad branch] (in Russian)

Косець M. I. (1947). Букові ліси Західного Поділля. Ботанічний журнал АН УРСР, IV(3-4), 101-114. [Kosets, M. I. (1947). Beech forests of West Podillya. Botany magazine Academy of Sciences USSR, IV (3-4), 101114] (in Ukrainian)

Краснитский А. М., Сошнин Г. П. (1984). Внедрение деревьев и кустарников на некосимых участках Центрально-Черноземного заповедника. Бюлл. Моск. о-ва испыт. природы. Отд. биол. Т. 89, вbın. 2. C. 88-97. [Krasnitsky, A.M., \& Soshnin, G.P. (1984). The introduction of trees and shrubs in the unmown parcels of Central Chernozem nature reserve. Bulletin Moscow Society of Nature Investigators. Section of Biology, 89(2), 88-97] (in Russian)

Криницький Г.Т., Попадинець I.M., Бондаренко В.Д., Крамарець В.О. (2004). Букові ліси Західного Поділля. Тернопіль: Укрмедкнига. 168 c. [Krynytsky, G.T., Popadynets, I. M., Bondarenko, V.D., \& Kramarets, V. O. (2004). Beech forests of West Podillya. Ternopil: Ukrmedknyha] (in Ukrainian)

Лазорко В. (1938). Фавна хрущів Лисої гори в Золочівському повіті. Львів: Збірник Фізіогр. Коміciï, 7, 3-11. [Lazorko, V. (1938). The beetle fauna of Lysa Hora IN Zolochiv county. Digest of Physiographical Comission, 7, 3-11] (in Ukrainian)

Ляска В. (2017). Лиса гора на Голих Горах. Отримано 3 Zbruc.eu/node/70905. [Lyaska, V. (2017). Bald moun- tain on the Bare Mountains. Retrieved from Zbruc.eu/ node/70905] (in Ukrainian)

Морозов Г.Ф. (1926). Учение о лесе. Изд. третье. Ленинград: Гос. изд-во, 368 с. [Morozov, G. F. (1926). The doctrine of the Forest. Third ed. Leningrad: State Publishers] (in Russian)

Одноралов В.С., Давидок В.П., Божко О.П., Олещенко В.І., Федоренко А.П., Фещенко П.І., ... Липа О.Л. (1986). Природно-заповідний фонд Украӥнської РСР. Реєстр-довідник заповідних об'єктів / за ред. М.А.Воїнственського. Київ, Урожай. 224 с. [Odnoralov, V.S., Davidok, V.P., Bozhko, O.P., Oleshchenko, V.I., Fedorenko, A.P., Feshchenko, P.Í., ...Lipa, O.L. (1986). Nature Reserve Fund of Ukrainian SSR. Directory register of protected areas. (Ed.) M.A. Voinstvensky. Kyiv: Urozhai] (in Ukrainian)

Оселищна концепція збереження біорізноманіття: базові документи Європейського Союзу (2012). Ред. О. О. Кагало, Б. Г. Проць. Львів: ЗУКЦ. 278 с. [Habitat concept of biodiversity conservation: basic documents of the European Union (2012). O. O. Kagalo, \& B. G. Prots (Eds). Lviv: ZUKC] (in Ukrainian)

Погребняк П.С. (1931). Лісорослинні умови Поділля. Праці Всесоюзн. науково-досл. ін-ту лісового госп-ва та агролісомеліораиії, 10, 5-120. [Pogrebnyak, P.S. (1931). Forest vegetation conditions of Podillya. Proceedings of the Whole-Union scientific research Institute of Forestry and Agriforestry, 10, 5-120] (in Ukrainian)

Почвоведение (1975). Изд. 2-е, перераб и доп. / под ред. И. С. Кауричева. Москва: Колос. 496 с. [Soil Science (1975). 2nd edition, revised and enlarged / I. S. Kaurichev (Ed.). Moscow: Kolos] (in Russian)

П'ятківський I. (2003). Сучасний стан мережі природно-заповідного фонду та перспективи іiі розвитку в Тернопільській області. Роль природно-заповідних територій Західного Поділля та Юри Ойиувської у збереженні біологічного та ландшафтного різноманіття: зб. наук. пращь. Гримайлів. С. 87-94. [Pyatkivsky, I. (2003). A present state of the protected areas network and perspectives of its development in Ternopil' region. Role of protected areas of West Podillia and Jura Ojcowska in the biological and landscape diversity conservation: scientific works collection. Hrymailiv, 97-94] (in Ukrainian)

Рідкісні та зникаючі види тварин Львівської області (2013). Ред. А.-Т. В. Башта, Ю. В. Канарський, М.П. Козловський. Львів: Ліга-Прес. 224 с. [Rare and threatened animal species of the L'viv region (2013). Bashta, A.-T., Yu. Kanarsky, M. Kozlovsky (Eds). Lviv, Ukraine: Liga-Press] (in Ukrainian)

Самарин В.Ф. (1982). Об устойчивости степных фитоценозов в условиях заповедности. Охрана растительных сообществ редких и находящихся под угрозой исчезновения экосистем: материалы I Всесоюз. конф. по охране редких растительных сообществ (Москва, 19 октября - 2 ноября 1981 г.). Москва, 1982. C. 61-63. [Samarin, V.F. (1982). On the resistance of steppe phytocenoses in the conservation con- 
ditions. Protection of plant communities of the rare and tendangered ecosystems: proceedings of the I All-Union conf. on the protection of rare plant communities. Moscow, 61-63] (in Russian)

Семенова-Тян-Шанская А. М.(1982). Режим охраны травяных растительных сообществ. Охрана растительных сообществ редких и находящихся под угрозой исчезновения экосистем: материалы I Всесоюз. конф. по охране редких растительных сообществ (Москва, 19 октября - 2 ноября 1981 г). Москва, 1982. С. 29-30. [Semenova-Tyan-Shanskaya, A.M. (1982). Protection regime for the grassland plant communities. Protection of plant communities of the rare and endangered ecosystems: proceedings of the I AllUnion conf. on the protection of rare plant communities. Moscow, 29-30] (in Russian)

Ткаченко В.С. (2004). Фітоиенотичний моніторинг резерватних сукиесій в Украӥнському степовому природному заповіднику. Київ: Фітосоціоцентр. 184 c. [Tkachenko, V.S. (2004). Phytocoenotic monitoring of reservation successions in the Ukrainian steppe nature reserve. Kyiv: Phytosociocenter] (in Ukrainian)

Фасулати К. К. (1971). Полевое изучение назкемных беспозвоночных. Москва: Высшая школа. 424 с. [Fasulati, K. K. (1971). The field studies of terrestrial invertebrates. Moscow: High school] (in Russian)

Штильмарк Ф.Р. (1981). Принципы заповедности (теоретические, правовые и практические аспекты). Географическое размешение заповедников в РСФСР и организаичи их деятельности: сборник научн. трудов. Москва: ЦНИЛ Главохоты РСФСР. С. 60-76. [Shtilmark, F. R. (1981). Principles of the nature conservation (theoretical, legal and practical aspects). Geographical location of the nature reserves in the RSFSR and organization of their activities. Collection of scientific. works. Moscow: Glavokhota Central Scientific Research Laboratory of the RSFSR. pp. 60-76] (in Russian)

Штильмарк Ф.Р. (1985). Определение и смысл заповедности. Организация заповедного дела. Алма-Ата: Кайнар. С. 35-36. [Shtilmark, F. R. (1985). Definition and sense of the nature conservation. In Organization of the nature reserve management (pp. 35-36). Alma-Ata: Kainar] (in Russian)

Ященко П.Т. (2010). Активна охорона фітосистем - становлення концепції і результати застосування у природоохоронних об'єктах. Природнозаповідний фонд Украӥни - минуле, сьогодення, майбутнє: матеріали міжнар. наук.-практ. конф., присвяченої 20-річчю природного заповідника «Медобори» (смт. Гримайлів, 26-28 травня 2010 р.). Тернопіль: Підручники і посібники. C. 108-113. [Yashchenko, P.T. (2010). Active protection of phytosystems - formation of the concept and results of its application in the nature protected areas. Nature Reserve Fund of Ukraine-Past, Present, Future, 108-113. Ternopil, Ukraine: Textbooks and manuals] (in Ukrainian)

Davies, C.E., Moss, D., \& O'Hill, M. (2004). EUNIS habitat classification revised 2004. Europaean Envi- ronment Agency. European Topic Centre on Nature Protection and Biodiversity. Retrieved from http:// eunis.eea.europa.cu/upload/EUNIS_2004 report.pdf

Freude, H., Harde K.-W., Lohse G. A., \& Klausnitzer B. (2004). Die Käfer Mitteleuropas. Band 2. Adephaga 1. Carabidae (Laufkäfer). 2. (erweiterte) Auflage. Spectrum, Heidelberg [Freude, H., Harde K.-W., Lohse G.A., \& Klausnitzer B. (2004). The beetles of Central Europe. Volume 2. Adephaga 1. Carabidae (ground beetles). 2nd (extended) edition. Spectrum, Heidelberg] (in Germany)

Gaewski W. (1937). Elementy flory polskiego Podola. Warszawa. Planta Polonica, 5. 211 s. [Gaewski, W. (1937). Elements of the flora of Polish Podolia. Warsaw. Planta Polonica, 5] (in Polish)

Hirschler J., Romaniszyn J. (1909) Motyle większe z okolic Lwowa. Spr. Kom. Fiz. P.A.U., 43, 80151. [Hirschler, J., \& Romaniszyn, J. (1909). Butterflies and larger moths from the vicinity of Lviv. Proceedings of Physiographical Comission P.A.U., 43, 80-151] (in Polish)

Hołowkiewicz E. (1890). Las na Podolu. Sylwan, 8. S. 2-11. [Hołowkiewicz, E. (1890). Forest in the Podolia. Sylvan, 8, 2-11] (in Polish)

Kaminski R. (1935). Kilka uwag o gospodarce leśnej na terenie Województwa Tarnopolskiego. Sylwan, 53 (4), 159-174. [Kaminski, R. (1935). A few remarks on forest management in the Tarnopol Province. Sylwan, 53 (4), 159-174] (in Polish)

Koczwara W. (1925). Granice florystyczne Podola. Kosmos, 50, 1285-1322. [Koczwara, W. (1925). Floristic boundaries of the Podolia. Kosmos, 50, 12851322] (in Polish)

Koczwara W. (1928). Z badan pylkowych nad torfowiskani Podola. Kosmos, A, 53, 109-120. [Koczwara, W. (1928). From the pollen research upon the peat bogs of Podolia. Kosmos, A, 53, 109-120] (in Polish)

Kudrna O., Pennerstorfer J. \& Lux K. (2015). Distribution Atlas of European Butterflies and Skippers. Schwanfeld: Wissenschaftlicher Verlag Peks i K.

Kuntze R. (1932). Wyniki badan nad fauna Chrząszczy Podola w latach 1930/32. Kosmos, 57(1-4), 257-265. [Kuntze, R. (1932). The results of research upon the fauna of Podolian beetles in 1930/32. Kosmos, 57(1-4), 257-265] (in Polish)

Kuntze R. (1936). Charakterystyka faunistyczna Łysej Góry pod Lackiem w powiecie złoczowskim. Prace Komisji dla badań krawędzi Podola Nr. 7. Kosmos, A, 61. S. 109-136. [Kuntze, R. (1936). Faunistical characteristics of the Lysa Gora site about Lackie in Zloczow county. Works of the Comission of investigations on the Podolian escarp No 7. Kosmos, A, 61, 109-136] (in Polish)

Lóbl, I., \& Smetana A. (2003). Catalogue of Palaearctic Coleoptera. Volume 1. Archostemata-Myxophaga - Adephaga. Apollo Books, Stenstrup

Łomnicki M. (1890). Fauna Lwowa i okolicy. 1. Chrząszcze (Coleoptera). Cz. 1. Sprawozdanie Komisyi Fizyjograficznej, Kraków, 25, 141-217. 
[Łomnicki, M. (1890). Fauna of Lwow and vicinity. I. Beetles (Coleoptera). Pt. I. Proceedings of Physiographical Comission, Krakow, 25, 141-217] (in Polish)

Miklaszewski J. (1928). Lasy i lesnictwo w Polsce. Warszawa. 629 s. [Miklaszewski, J. (1928). Forests and forestry in Poland. Warsaw] (in Polish)

Paczoski J. (1913). Wycieczka botaniczna na Podolie. Kosmos, A, 38, 1184-1220. [Paczoski, J. (1913). A botanical journey into Podolia. Kosmos, A, 38, 1184-1220] (in Polish)

Raciborski M. (1911). O sosnie (Pinus sylvestris L.) w Polsce. Kosmos, 36, 321-329. [Raciborski, M. (1911). About Commom Pine (Pinus sylvestris L.) in Poland. Kos mos, 36, 321-329] (in Polish)

Romaniszyn J., Schiller F. (1929). Fauna motyli Polski (Fauna Lepidoptera Poloniae). T. 1. Prace monograficzne Kom. fiziogr. PAU. T. 6. Krakow. 552 s. [Romaniszyn, J., \& Schiller, F. (1929). The Lepidoptera fauna of Poland (Fauna Lepidoptera Poloniae). The monographs of Kom. fiziogr. PAU. Vol. 6. Krakow] (in Polish)

Sokolowski St. (1901). Z lasow podolskich. Sylwan, 18, 1-11; 39-47. [Sokolowski, St. (1901). From the Podolian forests. Sylwan, 18, 1-11; 39-47] (in Poland)

Strzelecki H. (1894). O przyrodzonem rozsiedleniu drzew lesnych w Galicji. Sylwan, 12. S. 295-306. [Strzelecki, H. (1894). About the natural distribution of forest trees in Galicia. Sylwan, 12, 295-306] (in Polish)

Szafer W. (1910). Geobotaniczne stosunki Miodoborow galicyjskich. Rozpr. wydz. mat.-przyrodn. Pol. Akad. Um. Krakow, 50, 163-172. [Szafer, W. (1910). Geobotanical relations of Galician Miodoborow. Proceedings of the mathematics-natural sciences department, Polish Academy of Sciences. Krakow, 50, 163-172] (in Polish)

Szafer W. (1935). Las i step na Zachodnim Podolu. Rozpr. wydzialu mat.-przyrodn Pol. Akad. Um. Krakow. 71, B.2, 1-123. [Szafer, W. (1935). Forest and steppe in West Podolia. Proceedings of the mathematicsnatural sciences department, Polish Academy of Sciences, Krakow, 71, B. 2, 1-123] (in Polish)

Wierdak Z. (1925). O rozsiedleniu niektorych naszych drzew i krzewow. Sylwan, B. 42, 245-260. [Wierdak, Z. (1925). About the distribution of some our trees and shrubs. Sylwan, B.42, 245-260] (in Polish)

Wierdak Z. (1927). O kresowych stanowiskach naszych drzew. Sylwan, 45(2), 103-1145. [Wierdak, Z. (1927). About the positions of our trees in the borderlands. Sylwan, 45 (2), 103-145] (in Polish)

Zajączkowski M. (1936). O poludniowej granicy zasięgu sosny pospolitej w Polsce i o występowaniu reliktowej sosny w Karpatach Polskich. Krakow, $P A U$. 52 s. [Zajaczkowski, M. (1936). About the southern border of Common pine's range in Poland and the occurrence of relict pine in the Polish Carpathians. Krakow: Polish Academy of Sciences] (in Polish)

Zapałowicz H. (1906-1911). Krzytyczny przegląd roślinności Galicji. Conspectus florae Galicie criticus. Rozpr.Wydz. mat.-przyrod. Pol. Acad. Um. Krakow. T. 1-3. 296 s; 311 s.; 246 s. [Zapalowicz, H. (1906-1911).
Critical overview of vegetation of the Galizia. Conspectus florae Galicie criticus. Proceedings of the mathematicsnatural Sciences department, Polish Academy of Sciences, Vol. 1-3. 296 p; 311 p.; 246 p.] (in Polish).

\section{Afforestation of meadow-steppe and invertebrates' habitats in the nature protected areas of Holohory hilly range (environmental assessment of the phenomenon)}

\section{P. Yashchenko', Yu. Kanarsky², I. Shpakivska}

In recent decades, Ukraine has been revising the paradigm of absolute conservation and applying the transition to habitual principles of biodiversity conservation. This is due to the fact that the use of only the protected regime for the preservation of rarities of flora and rare plant communities does not ensure the complete preservation of their original composition and structure. This situation is typical for the nature protection objects of the Holohory hills, where the areas of extra-zonal meadow-steppe grassland vegetation have been preserved as habitats for rare species of plants and insects.

The article describes the natural features of the Hologir, highlights the history of the establishingof environmental facilities in the region. It is pointed that the botanical natural monument of state importance "Lysa Hora \& Hora Sypukha" with an area of 283 ha was establishe for the protection of beech shrub woodland. But the official description of the vegetation of this object states that the types of grasses listed in the Red Data Book of Ukraine grow in the steppe areas within its boundaries. This link shows that the natural monument actually had a small purpose - to preserve not only shrub woodland, but also meadowsteppe vegetation with rare species of flora and fauna of Ukraine, which confirms the significant sozological

Pavlo Yashchenko - Corresponding Member of the Forest Academy of Sciences of Ukraine, Candidate of Biological Sciences, Associate Professor, Senior Researcher, Department of Ecosystemology of the Institute of Ecology of the Carpathians, National Academy of Sciences of Ukraine, 4 Kozelnitska str., Lviv, 79026, Ukraine. Tel.: +38-097-344-74-82. E-mail: ecoinst08@ukr.net. E-mail: home@ mail.lviv.ua ORCID: 0000-0002-9246-9978

Yurii Kanarsky - Candidate of Biological Sciences, Senior Researcher, Department of Ecosystemology of the Institute of Ecology of the Carpathians, National Academy of Sciences of Ukraine, 4 Kozelnytska str., Lviv, 79026, Ukraine. Tel.: +38-067602-51-22. E-mail: ykanarsky@gmail.com ORCID: 0000-00028426-3072

Irina Shpakivska - Candidate of Biological Sciences, Senior Researcher, Head of the Department of Ecosystemology of the Institute of Ecology of the Carpathians, National Academy of Sciences of Ukraine, 4 Kozelnitska str., Lviv, 79026, Ukraine. Tel.: +38-050-519-39-51. E-mail: ishpakivska@ukr.net ORCID: 0000$0002-5152-6083$ 
value of the object. However, the artificial afforestation of the top of Lysa Hora with Common pine and Banks pine and their subsequent spontaneous settlement in steppe areas has a negative effect on the preservation of grass vegetation and some Invertebrata communities. An analysis of the literature on the distribution of Common pine in Podillya in the past reflects the divergence of scholars' views on its autochthony. The impact of afforestation (silvatization) on the meadow-steppe vegetation and invertebrates has been characterized from a conservation standpoint. It is concluded that the presence of pine in Hologory nature reserves does not meet the purpose of their creation, and the spontaneous expansion of this species leads to degradation of habitats of meadow-steppe vegetation and groups of insects that are subject to protection. As a result of artificial and spontaneous afforestation of meadowsteppe areas, the whole xerophilous complex of the Carabidae fauna disappears. The general analysis of trends in the number of of habitat groups of butterflies butterflies in meadow-steppe habitats Holohir over the past 25 years has shown a significant decrease in the frequency of ecotone mesophiles, steppe xerophiles and meadow hygrophiles. It is expedient to apply active preservation of mesoxerophytic herbaceous groups and groups of invertebrates by regular removal of pine and hazel self-seedingfrom their habitats.

Key words: paradigm; botanical monuments of nature; xeromesophytic herbaceous communities; planted pine forest; spontaneous afforestation of slopes; rare species of plants and insects.

\section{Сильватизация местообитаний лугово-степной растительности и беспозвоночных в природоохранных объектах Гологорского холмогорья (природоохранная оценка явления)}

\author{
П.Т. Ященко' ${ }^{1}$ Ю. В. Канарский ${ }^{2}$ \\ И.М. Шпакивская ${ }^{3}$
}

В последние десятилетия в Украине пересматривается парадигма абсолютной заповедности и осуществляется переход к охране местообитаний (габитатов) для сбережения биоразнообразия. Это обусловлено тем, что применение только заповедного режима для сохранения раритетов флоры и фауны, редкостных растительных сообществ не обеспечивает полного сбережения их первоначального состава и структуры. Такая ситуация характерна для природоохранных объектов в пределах Гологорского холмогорья, где сохранились участки экстразональной лугово-степной растительности как местообитания редкостных видов растений и насекомых. В статье охарактеризованы природные особенности Гологор, отражена история создания в этом регионе природоохранных объектов. Отмечено, что ботанический памятник природы государственно- го значения «Лысая Гора и Гора Сипуха» площадью 283 га был создан для охраны бучин кустарниковых. Но в официальном описании растительности этого объекта указано, что на степных участках в его пределах растут виды трав, занесенные в Красную книгу Украины. Эта ссылка свидетельствует, что памятник природы фактически имел и имеет двойную цель - сохранение не только бучин кустарниковых, но и лугово-степной растительности с редкостными представителями флоры и фауны Украины, что подтверждает значительную созологическую ценность объекта. Однако искусственное облесение верховий горы Лысой сосной обыкновенной и сосной Банкса, дальнейшее спонтанное их расселение на степные участки негативно сказывается на сохранении травяной растительности и группировок беспозвоночных. Анализ литературы по распространению сосны на Подолье в прошлом свидетельствует о расхождении взглядов ученых на ее автохтонность. Влияние облесения (сильватизации) местообитаний лугово-степной растительности и беспозвоночных рассмотрено с природоохранных позиций. Сделан вывод, что наличие сосны в природоохранных объектах Гологор не соответствует цели их создания, а спонтанное расселение этой породы приводит к деградации местообитаний лугово-степной растительности и группировок насекомых, подлежащих охране. В результате исчезает целый ксерофильный комплекс карабидофауны. Общий анализ трендов изменения численности отдельных биотопических групп дневных бабочек в лугово-степных местообитаниях Гологор за последние 25 лет показал значительное уменьшение частоты встречаемости экотонных мезофиллов, степных ксерофилов и луговых гигрофилов. Необходимо активное сохранение мезоксерофитних травостоев и группировок беспозвоночных путем регулярного изъятия из их местообитаний самосева сосны и лещины.

Ключевые слова: парадигма; ботанические памятники природы; ксеромезофитные травяные группировки; лесные культуры сосны; спонтанное облесение склонов; редкостные виды растений и насекомых.

\footnotetext{
Ященко Павел Тихонович - член-корреспондент Лесной академии наук Украины, кандидат биологических наук, доцент, старший научный сотрудник отдела экосистемологии Института экологии Карпат НАН Украины, ул. Козельницкая, 4, г. Львов, 79026, Украина. Тел.: +38-097-344-74-82. E-mail: ecoinst08@ukr.net. E-mail: home@mail.lviv.ua ORCID: 0000-0002-9246-99782

Канарский Юрий Васильевич - кандидат биологических наук, старший научный сотрудник отдела экосистемологии Института экологии Карпат НАН Украины, ул. Козельницкая, 4, г. Львов, 79026, Украина. Тел .: +38-067-602-51-22. E-mail: ykanarsky@gmail.com ORCID: 0000-0002-8426-30723

Шпакивская Ирина Мироновна - кандидат биологических наук, старший научный сотрудник, заведующая отделом экосистемологии Института экологии Карпат НАН Украины, ул. Козельницкая, 4, г. Львов, 79026, Украина. Тел.: +38-050519-39-51. E-mail: ishpakivska@ukr.net ORCID: 0000-0002$5152-6083$
} 